ARTICLE

\title{
Targeted advertising: documenting the emergence of Gun Culture 2.0 in Guns magazine, 1955-2019
}

David Yamane (10 ${ }^{1 凶}$, Paul Yamane ${ }^{2} \&$ Sebastian L. Ivory ${ }^{3}$

\begin{abstract}
This study replicates Yamane, Ivory, and Yamane's (Gun studies: interdisciplinary approaches to politics, policy, and practice, Routledge, New York, pp. 9-27, 2019) earlier analysis of the rise of self-defense in gun advertisements in The American Rifleman. It uses the same methodological procedures and applies them to a for-profit, general interest firearm magazine that has been continuously published for 65 years: Guns magazine. Like the earlier study, we hypothesize that the center of gravity in US gun culture has evolved over time from "Gun Culture 1.0," the historic gun culture of hunting and recreational shooting, to "Gun Culture 2.0," America's contemporary defensive gun culture, an evolution reflected in the content of gun advertisements. The data show that the predominance of Gun Culture 1.0 themes in advertising persists through the 1980s and into the 1990s, when the center of gravity of gun culture begins to shift decisively toward the Gun Culture 2.0 themes of personal protection/self-defense and concealed carry. This trend continues through the 1990 s and 2000s, with the two emphases crossing-over in the 2010s. As reflected in advertising, in addition to other indicators such as self-reported reasons for gun ownership, Gun Culture 2.0 is now America's dominant and still expanding core gun culture today.
\end{abstract}

\footnotetext{
${ }^{1}$ Wake Forest University, Winston Salem, NC, USA. ${ }^{2}$ Independent Scholar, Winston Salem, NC, USA. ${ }^{3}$ Wesleyan University, Middletown, CT, USA.

凶email: yamaned@wfu.edu
} 


\section{Introduction}

$s$ others have argued at great length, guns were part of the social reality of the United States well prior to its Declaration of Independence from the British crown and its Constitutional founding (Cramer, 2006; Dunbar-Ortiz, 2018; Winkler, 2011). Self-defense has been part of American gun culture for just as long. Eighteenth century versions of the same defensive "pocket pistols" that dominate today's concealed carry marketplace (Yamane, 2019) can be found in any museum with a substantial firearms collection. The importance of having a defensive firearm ready at hand can be seen in late nineteenth century advertisements for Smith \& Wesson's "bicycle revolver" in Forest and Stream magazine and Forehand Arms Co.'s "That dog will never bark again!" advertisement in Recreation magazine. The latter depicts a man riding a bicycle in the countryside discharging a revolver in the direction of a dog that has (presumably) run up on him. The text of the ad continues, "If you want to be well armed against dogs, foot-pads, burglars and book agents, buy a Forehand".

In the early twentieth century, Iver Johnson advertised their revolvers for home defense in Collier's National Weekly with the tag line "Now you won't feel afraid". ${ }^{1}$ Moreover, as motor cars became more accessible to the masses in the 1920s, the need for personal protection while driving was emphasized in Colt's firearms "Safety of the Highways" advertisement. A drawing shows a woman in the driver's seat of a parked car with a motorcycle police officer next to her with his gun drawn. In the background we see two individuals scampering off. Anticipating the contemporary phrase, "When seconds count, police are just minutes away", the subheading in the Colt's ad reads, "Suppose he had not arrived". With the exception of the bicycle gun, parallel advertisements for defensive firearms can be seen in abundance today. To take but one example, Remington's "Live Ready" campaign for the R51 subcompact handgun mirrors Colt's earlier ads by highlighting potential threats while driving. Here, the view is from the perspective of the driver who is pulled over to the side of the road looking out at a vast swath of desert ahead. We also see another car pulled over in the rear view mirror. The caption: "He's not here to fix your flat".

The existence of eighteenth century pocket pistols and nineteenth/early twentieth century self-defense-based gun advertising highlights the continuity of gun culture over a long period of time (Haag, 2016). However, this does not mean that nothing has changed over the past 300 years. Examining contemporary American society, a number of observers highlight significant developments among the at least $30 \%$ of US adults who own nearly 400 million firearms (Karp, 2018). ${ }^{2}$ Although the motivations for gun ownership are complex, the majority of gun owners today-especially new gun owners-point to self-defense as the primary reason for owning a gun (Wertz et al., 2018). In a 1999 ABC News/Washington Post poll, 26\% of respondents cited protection as the primary reason for owning a gun; by 2013, that proportion had grown to $48 \%$. Hunting, target/sport shooting, and gun collecting together declined by a roughly equal amount (Pew Research Center, 2013). The 2015 National Firearms Survey found $63 \%$ of respondents indicated "protection against people" to be a primary reason for owning a firearm (Azrael et al., 2017). More recently, a 2017 Pew Research Center survey confirms this trend, finding two-thirds of gun owners $(67 \%)$ responding that protection is a major reason why they own a firearm, including $65 \%$ of men and $71 \%$ of women. In the same survey, $38 \%$ cited hunting and $30 \%$ sport shooting as major reasons for gun ownership (Gramlich and Schaeffer, 2019).

These statistics parallel the changing legal structure governing the carrying and use of firearms for self-defense. Two hundred years after Kentucky banned the carrying of concealed weapons in public in 1813, state or local governments in all fifty states must have some provision in place for issuing permits to citizens allowing them to carry concealed firearms in public. More liberal "shall issue" laws WeWore restrictive "may issue" laws (Steidley, 2019a, 2019b). Vermont has never banned the practice of carrying a concealed weapon without a permit and so does not issue concealed-carry permits. Permitless carry represents the next phase of this liberalization of gun laws. Including Vermont, fifteen states now allow individuals to carry a concealed weapon in public without a permit, with certain restrictions and exceptions.

Although we recognize the contuining existence of various subcultures of guns in the US (Kohn, 2004; Luke, 2019; Taylor, 2013), these changes suggest the movement of self-defense to the core of American gun culture today. With this shift, previously dominant subcultures like hunting and recreational target shooting (Hofstadter, 1970) have become more marginal. The US Fish \& Wildlife Service's (2018) quinquennial survey of fishing, hunting, and wildlife-associated recreation reports that in 1991, $7 \%$ of the US population aged 16 and over hunted in 1991. By 2016, this proportion had dropped to $4 \%$. Gun journalist Michael Bane calls this an evolution from "Gun Culture 1.0" to "Gun Culture 2.0." Gun Culture 2.0 centers on home and personal protection through armed citizenship, notably the legal carrying of concealed weapons, mostly handguns, in public by ordinary Americans (Yamane, 2017; Carlson, 2015).

\section{Studying gun culture through advertising}

Although examining changes in public opinion and the law are important to documenting the emergence of America's new defensive gun culture, these data only track changes back two to three decades. Using advertising as data affords the opportunity to double or triple that time frame for understanding the nature of and changes in gun culture.

As Hofstadter (1970) noted, without guns there would be no gun culture. The humanly fabricated objects themselves are central to the material culture of guns. They circulate, initially, as commodities in the consumer marketplace. As cultural sociologist Wendy Griswold (2013) has argued, following Richard Peterson (1978), a complex apparatus exists connecting connecting producers and consumers of cultural objects. "This apparatus includes facilities for production and distribution; marketing techniques such as advertising, co-opting mass media, or targeting; and the creation of situations that bring potential cultural consumers in contact with cultural objects" (Griswold, 2013, p. 73). Therefore, gun advertising, like all advertising, exists to sell products to consumers.

But what products are sold, how, and why? Answering these questions highlights the fact that the process of connecting products and consumers is not simply organizational but meaningful as well. Sociologists have long recognized that advertising represents and promulgates certain values, beliefs, knowledge, and norms. Early views like that of Frankfurt School theorists Horkheimer and Adorno (1944 [2007]) saw advertising as false-consciousness inducing propaganda designed to perpetuate the culture industry's mass deception. In some ways, Vance Packard's (1957) best-selling book The Hidden Persuaders replicates the manipulation thesis of Horkheimer and Adorno, suggesting that advertisers use psychological techniques to control consumer behavior. Some critics of American gun culture similarly accuse gun manufacturers of using advertising to manipulate people into buying dangerous products they do not "need" (Diaz, 1999).

Although no fan of the advertising industry himself. Schudson (1984) sought to disrupt this mechanical and simplistic understanding of the power of advertising vis-à-vis consumers. To take 
but one clear example, although it is easy to imagine that advertising drives sales, it is often the case that sales drive advertising. Schudson offers the example of Volkswagen sales in the 1950s. Notable advertising campaigns for the cars followed rather than preceding those sales. Schudson argues that advertisers cannot simply manipulate consumer behavior. Rather, advertisers and advertising attempt to take people's values and interests and connect them to particular products using information, symbols, images, and emotions. This suggests a turn away from a materialist-either Marxist or rational-choicemodel of advertising toward a more cultural one.

Although the reception of advertising by protential consumers is not mechanical (Hall, 1980; Press, 1991), like other media artifacts ads can be read as a "discourse" within which cultural meanings circulate (Dawson, 2019). The question becomes how those meanings and the social practices they reflect change over time. Although not explicitly stated, such a perspective underwrites Yamane et al.'s (2019) original analysis of the changing content of gun advertising as a reflection of changes in the core of gun culture. We adopt the same approach here.

\section{Study of American Rifleman being replicated}

To access a longer-term perspective on shifting emphases within American gun culture, Yamane et al. (2019) conducted a systematic content analysis of advertisements in The American Rifleman magazine for every year from 1918 to 2017. They documented a steady pattern of decline of Gun Culture 1.0 over the past 100 years and the ongoing rise of Gun Culture 2.0. They also identified the point at which the two centers of gravity in gun culture crossed paths in the early 2010s.

The American Rifleman is a good choice for such an analysis, as the oldest and most widely circulated gun magazine (Hardy, 2012; Rajala, 2012). Part of its circulation strength, however, is because it is offered as a member benefit to National Rifle Association (NRA) members. As an official publication of the NRA, it is possible that its advertising content is biased by the NRA's political interests. Also, the NRA publishes other magazines focusing on hunting (American Hunter, since 1973) and the Second Amendment (American Guardian/America's First Freedom, since 1997) that members can choose instead of The Rifleman. Therefore, it is possible that changes in the content of the advertising in The Rifleman reflects the availability of these other magazines rather than a change in the core emphasis of gun culture. For example, if hunting appears less in advertising in The American Rifleman over time, is that explained in part by the availability of American Hunter for advertisers to target hunters?

This paper, therefore, replicates Yamane et al.'s (2019) earlier analysis of the rise of self-defense in gun advertisements in The American Rifleman. It uses the same methodological procedures and applies them to a for-profit, general interest firearm magazine that has been continuously published for 65 years: Guns magazine. Like the earlier study, we hypothesize that the center of gravity in US gun culture has evolved over time from Gun Culture 1.0, the historic gun culture of hunting and recreational shooting, to Gun Culture 2.0, America's contemporary defensive gun culture, an evolution reflected in the content of gun advertisements.

\section{Data and methods}

This study analyzes advertising in the second oldest general interest gun magazine in the United States: Guns. The magazine has been continuously published since 1955 , currently by FMG Publications in San Diego. It has a circulation of 74,333, fewer than Handguns magazine $(113,166)$ but more than Rifle Shooter
$(55,903)$, among magazines that submit to audits by the Alliance for Audited Media.

Sampling. The sample of advertisements analyzed in this study comes from a single randomly selected issue of Guns for each of the 65 years from 1955 through 2019. ${ }^{4}$ We used a random number generator set from 1 (January) to 12 (December) to determine which of the 12 monthly issues to examine for each year. We then acquired the specified issues either from the first author's collection (for more recent issues), by purchasing them through eBay or from FMG Publications (for older issues), or by taking advantage of FMG Publications' online archive of back issues.

Following Yamane et al. (2019), to be included in the sample, an advertisement had to meet three main criteria. First, the ad had to be at least one-quarter of a page in size. Second, the ad had to be placed by the manufacturer, licensed dealer, or importer of the product. Ads placed by comprehensive sporting goods stores or gun stores were not coded unless the store was selling their own brand of product. Third, the ad had to be for firearms (handguns, rifles, shotguns, or a variety of gun types), ammunition (but not separate parts of ammunition or reloading equipment), gun accessories (products designed to be attached to or affect the utility of a firearm in some way), or some combination of these products. These inclusion criteria resulted in a total of 1154 advertisements from 65 issues of Guns magazine.

Coding. Our content analysis began with nine themes: technical superiority, hunting, collecting, military, law enforcement, sport/ recreation, tactical, personal protection/self-defense/home or family defense, and concealed carry (Saylor et al., 2004). After dropping advertisements that had none of these nine themes, we were left with 950 advertisements. The most common type of ad that had no codeable themes was one that simply depicted the product and provided a name or basic factual information about it.

As our interest is in examining the shift from Gun Culture 1.0 to Gun Culture 2.0, we focus here on just four of these themes, described in Table 1. Of these four themes, hunting and sport shooting are reflective of the older Gun Culture 1.0, and personal protection/self-defense/home or family defense and concealed carry are reflective of the newer Gun Culture 2.0.

Following Yamane et al. (2019), we coded all themes present in each advertisement as many reflected multiple themes. Hunting and sport shooting are often found together, though are not identical. Likewise, many products coded for concealed carry are also coded for personal protection/self-defense, but they too are distinct categories.

Inter-coder reliability tests. As a test of the reliability of the coding scheme and instructions that were developed, the three researchers coded the first 10 advertisements meeting the selection criteria from the February 2017 issue of Guns magazine and the July 2016 issue of American Rifleman, for a total of 20 advertisements. Researchers coded each ad for the presence $(=1)$ or absence $(=0)$ of the attributes of interest. Krippendorfs $\alpha$ (alpha) was used to assess inter-coder reliability. According to Krippendorf (2013), it is customary to require $\alpha \geq 0.800$ to conclude that the coding scheme and instructions are reliable. ${ }^{5}$

As reported in Table 2, in the first round of testing, coding of 2 of the 4 attributes resulted in satisfactory levels of inter-coder reliability: hunting $(\alpha=0.92)$ and concealed carry $(\alpha=1.00)$. Coding of the other two attributes did not meet Krippendorf's 
Table 1 Gun magazine advertisement coding scheme.

Code Code definition

Hunting

Sport/recreation

Personal protection/self-defense/home or family defense

Concealed carry
Product is associated with hunting, through images (e.g., owner in hunting-related camo, animals in cross hairs) or text (e.g., "small game")

Product is promoted for informal recreational shooting (except hunting), or linked to any of the various shooting sports, precision rifle, clay target shooting, action shooting sports (3-gun, USPSA, IPSC, IDPA), Olympic shooting, etc., through images (e.g., a shot timer, clay pigeons,) or text (e.g., "competition," "plinking")

Product is portrayed as an effective and/or important means of home, family, and/or personal or self-protection, through images (e.g., confronting an assailant in a parking lot or alley, hiding behind bed with gun) or text (e.g., "engineered to defend," "comfort runs in our family, so you can protect yours")

Product is portrayed as designed to facilitate the carrying of a concealed firearm, through images (e.g., an inside the waistband holster) or text (e.g., "IWB," "carry more comfortably")
Table 2 Inter-coder reliability tests (Krippendorf's $\alpha$ ).

\section{Code}

Round 1 Round 2 Round 3 Round 4

Hunting

Sport/recreation

Personal protection/self-

defense/home or family

defense

Concealed carry

0.92

1.00

0.90

0.85
0.79

0.85

0.52

0.69

0.84

0.81

0.64

0.86

1.00

0.64

1.00

0.84

suggested $\alpha \geq 0.80$ : sport/recreation $(\alpha=0.52)$ and personal protection/self-defense/home or family defense ( $\alpha=0.64)$.

After a discussion of the application of the coding scheme and refinement of code definitions, a second round of coding was undertaken, comparing three researchers' coding of ten advertisements from the November 2013 issue of Guns magazine and ten advertisements from the May 2012 issue of The American Rifleman. Although Krippendorf's $\alpha$ increased for two attributes -Sport from 0.52 to 0.69 and Personal Protection from from 0.64 to 0.86 - Sport remained below the acceptable level of 0.80 . In addition, Concealed Carry dropped from 1.00 to 0.64 .

After further discussion and refinement of the coding definitions, a third round of coding was undertaken, comparing three researchers' coding of ten advertisements from the August 1966 issue of Guns magazine, 10 advertisements from the July 1969 issue of Guns magazine, and 20 advertisements from the December 1969 issue of The American Rifleman. In the third round of testing, three of the four attributes of interest had satisfactory levels of inter-coder reliability: hunting $(=0.90)$, sport $(=0.85)$, and concealed carry $(=1.00)$. Personal protection dropped from round 2 to round 3, but was very close to adequate still, with Krippendorf's $\alpha=0.79$.

Further refinements led to a fourth round of coding of 12 advertisements in the April 2000 issue of Guns and 13 advertisements in the October 2000 issue of The American Rifleman. As shown in Table 2, all four attributes of interest had Krippendorf's $\alpha>0.80$, ranging from 0.81 for personal protection/ self-defense/home or family defense to 0.85 for hunting. At that point, trained researchers coded advertisements independently, with the lead investigator spot-checking the results.

Analysis. Later issues of Guns magazine contain more advertisements than earlier issues. The average number of ads for the 65 -year period covered is 14.6/issue. The average for the first 5 years (1955-1959) is 10/issue, peaking during Barak Obama's first presidential term at 26.8/issue (from 2010-2014), and declining back to 13.2 /issue in the most recent 5 years (2015-2019).
Therefore, we normalize our results for each individual year. Rather than giving each advertisement equal weight and calculating the percentage of advertisements in each issue that reflect a particular theme, we normalize the advertising content by looking at the proportion of all advertising space as the denominator. We do this by recording and adding together the size of each ad that meets our selection criteria for each issue (two, full, half, third, or quarter page). The total coded advertising space averages 9.98 pages over the 65 years, and ranges from 1.99 pages in the March 1964 issue to 26.8 pages in the November 2013 issue.

We then multiply the presence of each coding theme in each advertisement by the size of the ad. For example, a half page ad for a hunting rifle is 0.5 , a one-third page ad for a concealed carry holster is 0.33 , and so on. Combining those products for each advertisement in each issue then dividing them by the total coded advertising space produces the percentage of total advertising space with that particular attribute. For example, 6.65 advertising pages in the September 1970 issue included hunting as a theme, out of 9.97 total advertising pages coded in that issue. So, $66.7 \%$ of all coded advertising space in that issue of Guns included hunting as a theme.

\section{Results}

Examining Gun Culture 1.0 themes of hunting and sport/ recreational shooting first, we see that these themes are present throughout the 65 years of advertising in Guns magazine we analyzed. However, the relative proportion of all advertising space coded that reflected these themes declined by 2019 . The two themes did show different patterns over the century examined. The red trendline in Fig. 1 shows the pattern for hunting. Similar to Yamane et al. (2019), we find hunting as a theme in gun advertising increased through the 1960s, and then declined the rest of the period under study.

This increase in the presence of the hunting theme in Guns in the 1960 s is likely reflective of the strong interest in outdoor recreation in the broader culture during this time period, including fishing, visiting National Parks, and RV camping (Wright et al., 1983, pp. 53-55; Pergams and Zaradic, 2008). However, even as these outdoor recreation activities continued to grow through the 1970s, the representation of hunting in gun advertising began declining, signaling a shift in the core of gun culture away from hunting. This suggests that the similar change documented by Yamane et al. (2019) in The American Rifleman is not due to the National Rifle Association's launch of American Hunter in 1973 as a competing magazine for NRA members. These fluctuations also remind us of the importance of looking at the overall trend (in red), and remembering that these trend lines only capture part of all of the change (e.g., in Fig. 1, Rsquare $=0.42$ ). 


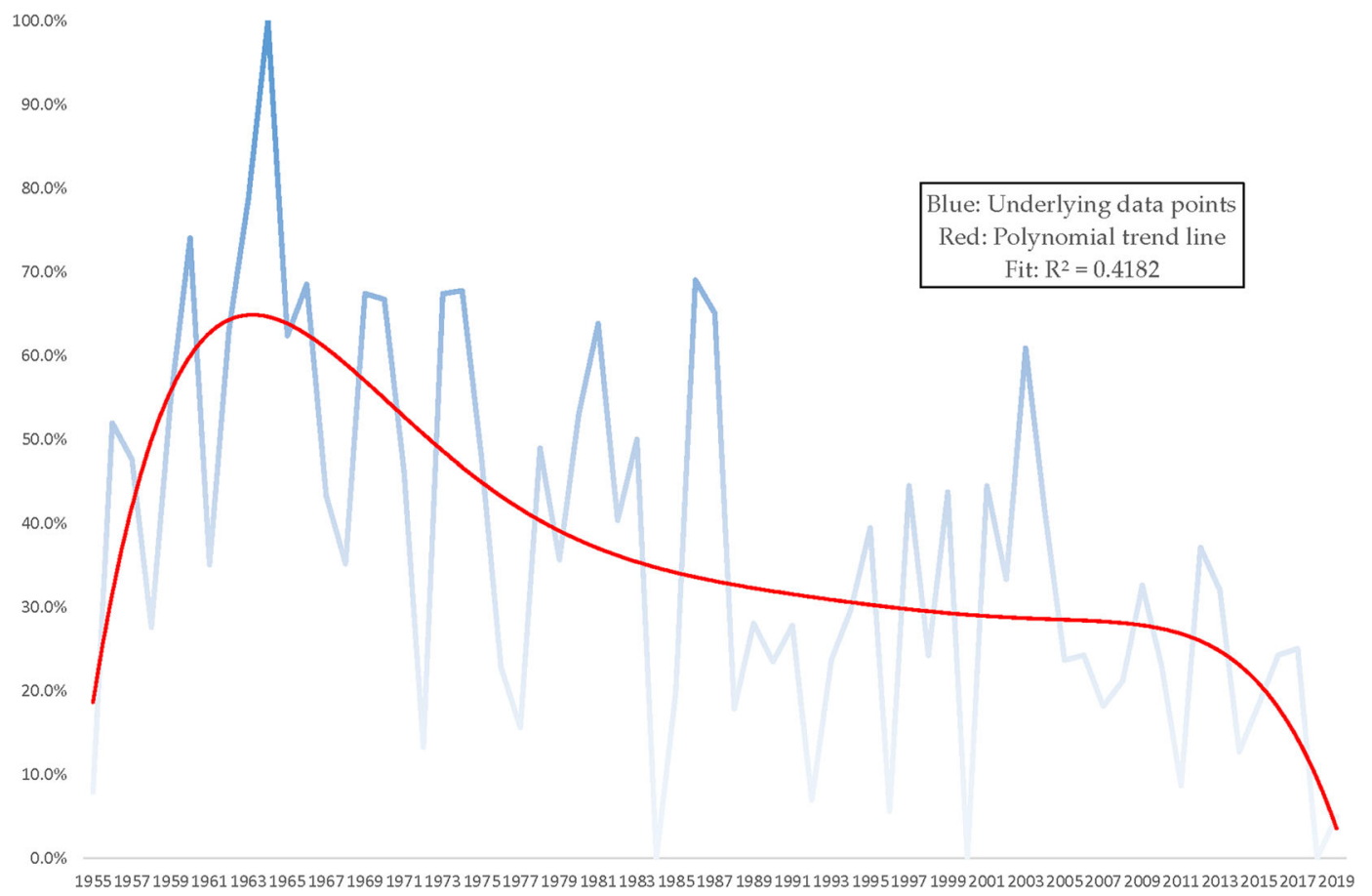

Fig. 1 Hunting theme as percentage of total coded advertising space, Guns Magazine, 1955-2019.

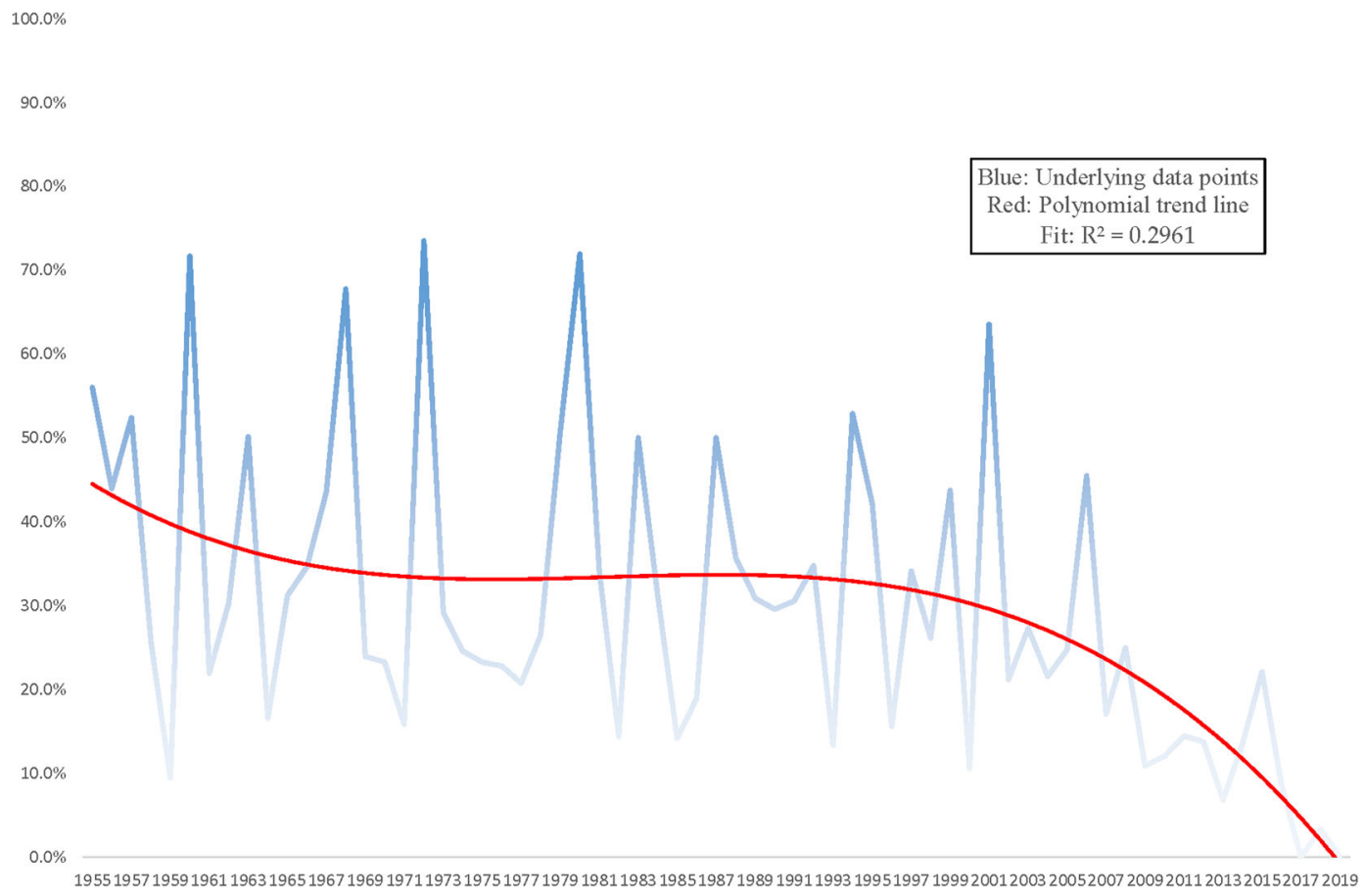

Fig. 2 Sport/recreational shooting theme as percentage of total coded advertising space, Guns Magazine, 1955-2019.

In Fig. 2, we see the sport and recreational shooting theme relatively stable as a percentage of the total advertising space for most of the period under study, then showing a pattern of steady decline in the last third. That said, the Gun Culture 1.0 themes of sport and recreational shooting continued to be an important part of American gun culture even as it declined as a proportion of advertising we coded. Taken together, hunting and sport and recreational shooting accounted for the majority of advertising space coded through the end of the twentieth century, even as the overall pattern for both is one of decline (Fig. 3).
As noted in the introduction, personal protection and home defense was already a theme in some gun advertising in the late nineteenth and early twentieth century. However, ads drawing on any of the themes in the broad category of personal protection/ self-defense/home or family defense were exceptional for the first half of the period under study here. As shown in Fig. 4, this Gun Culture 2.0 theme began to gain strength in the 1980s, indicated by the green trendline edging upward from that point forward.

Not coincidentally, Florida's landmark shall issue concealed carry legislation was signed into law in 1987 (Grossman and Lee, 


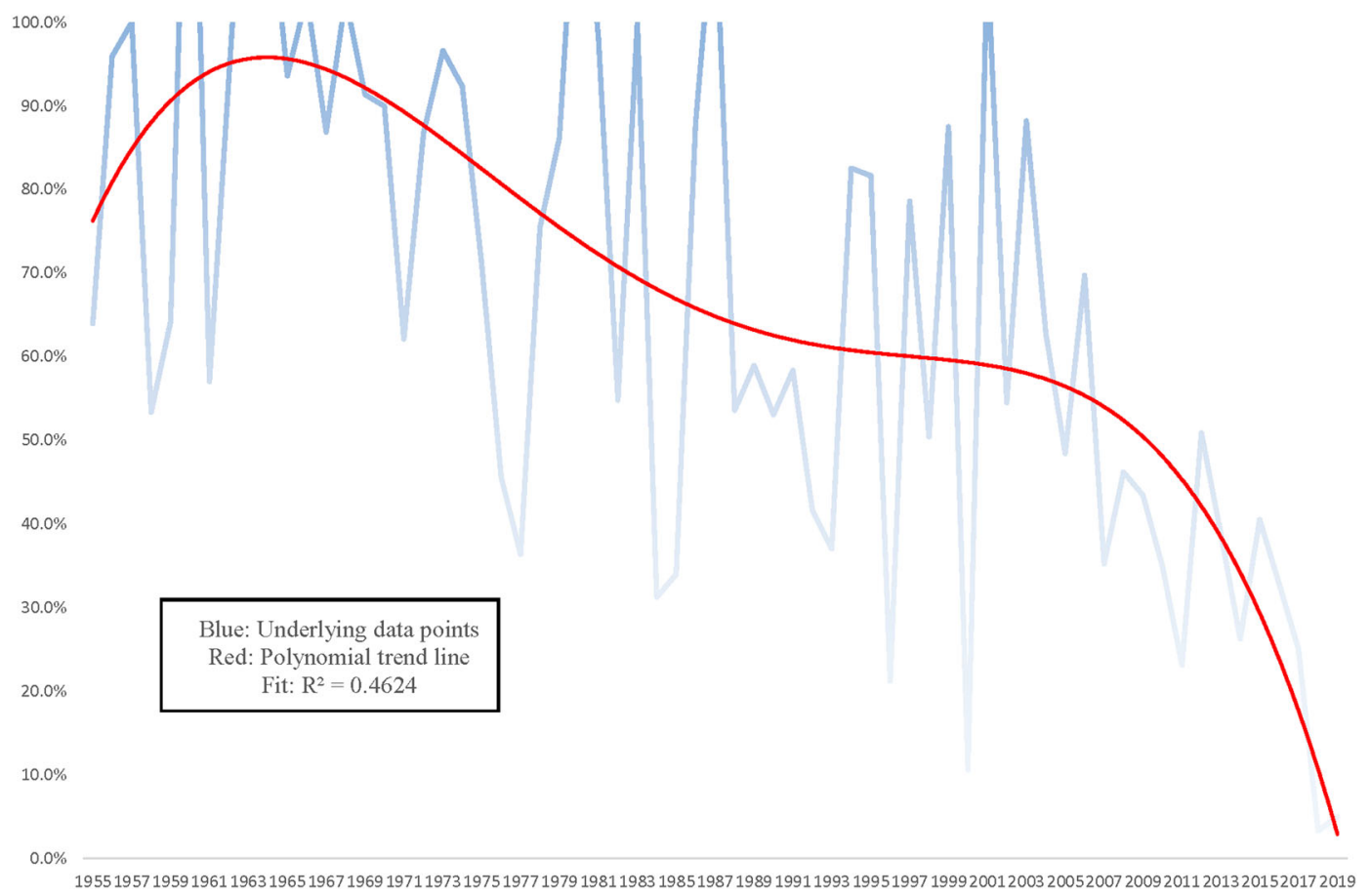

Fig. 3 Hunting and sport shooting themes as percentage of total coded advertising space, Guns Magazine, 1955-2019.

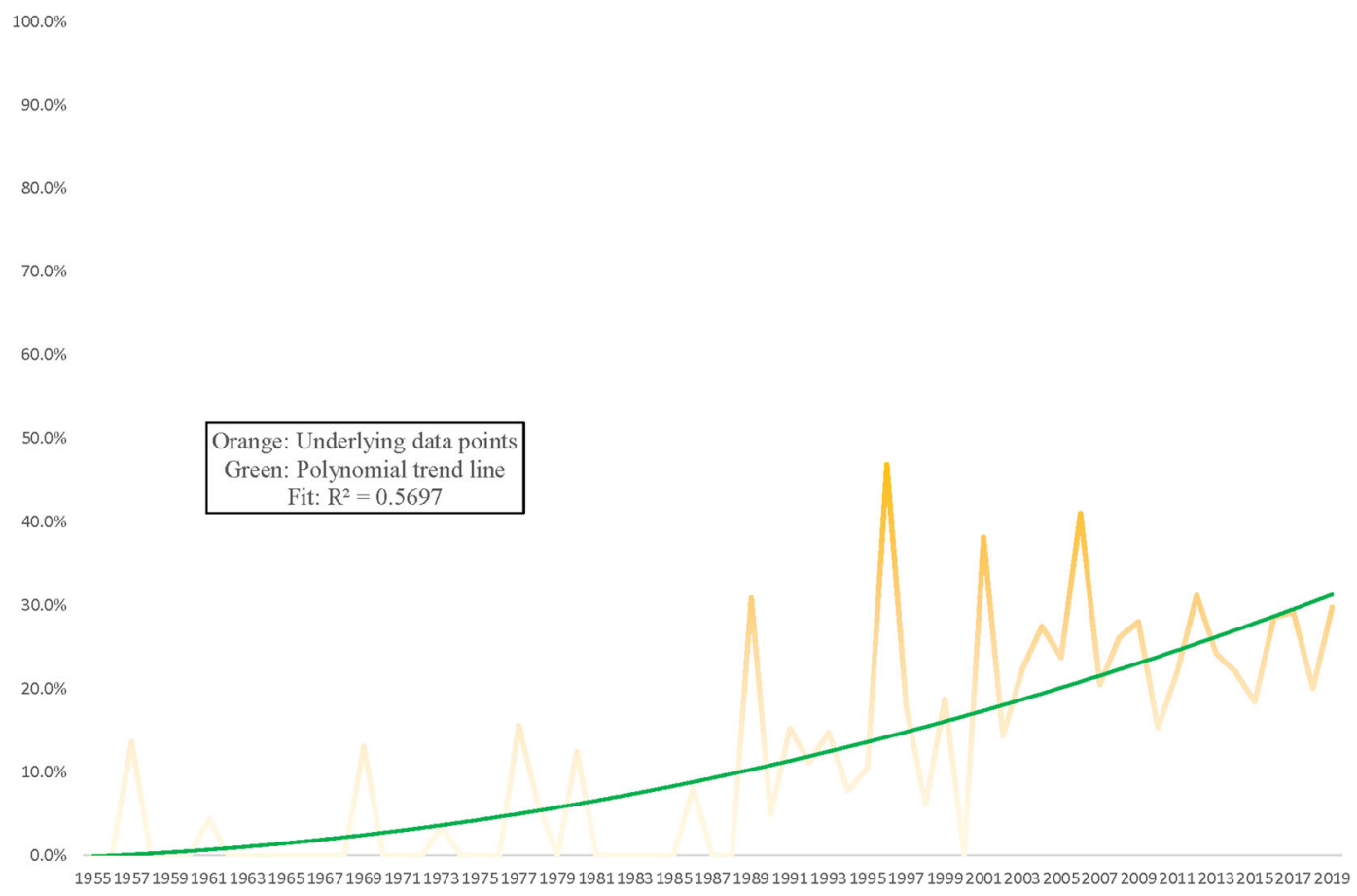

Fig. 4 Personal protection/self-defense theme as percentage of total coded advertising space, Guns Magazine, 1955-2019.

2008; Steidley, 2019a; Yamane, 2019). Although Florida did not create shall issue concealed carry, it did open the floodgates for a massive expansion in the number of states with liberalized concealed carry laws. By 1990, a dozen states had laws favoring the right-to-carry concealed weapons by ordinary citizens (Cramer and Kopel, 1994), and over the next 6 years, that number more than doubled as another 16 states passed shall issue laws.

This dramatic liberalization of concealed-carry laws has led to a growing number of Americans with concealed carry permits. These permit-holders, as well as those who can legally carry without a permit in the growing number of permitless carry states, represent a burgeoning market of consumers. They hunger in particular for commodities that promise to address the challenges of carrying a sufficiently lethal weapon in public in a manner that is safe, accessible, comfortable, and concealed (Yamane, 2019). This is reflected in the upward trend in advertising drawing on the concealed carry theme shown in Fig. 5. This theme reveals a pattern similar to that of personal protection/selfdefense, but with a slightly delayed onset and slightly steeper increase in the trend. 


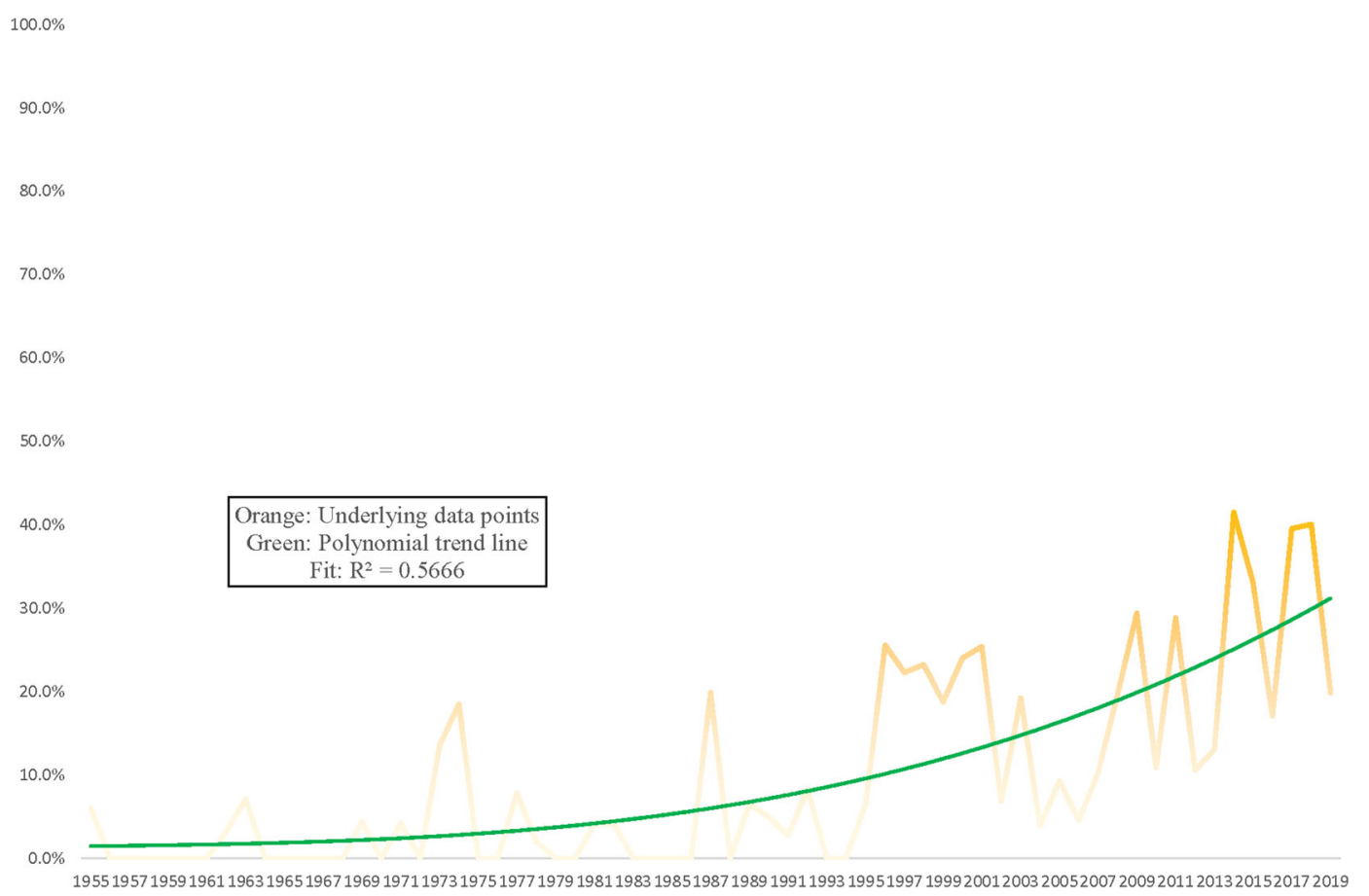

Fig. 5 Concealed carry theme as percentage of total coded advertising space, Guns Magazine, 1955-2019.

To return to the questions posed at the outset, then, has the core of American gun culture shifted from hunting and sport shooting to personal protection/self-/home and family defense and concealed carry? As measured through gun advertising, we conclude yes. Gun Culture 1.0 themes are found in a declining proportion of advertisements in Guns magazine over the past 65 years, and Gun Culture 2.0 themes are increasing.

Although their trajectories are converging, have Gun Culture 2.0 themes overtaken Gun Culture 1.0 themes in advertising? To answer this question, we combined the proportion of ads with the hunting and sport/recreational shooting themes, and the proportion of ads with the personal protection/self-/home and family defense and concealed carry themes. We then plotted those two trends together on the same graph. Figure 6 shows the convergence of the trend lines for these two themes from the 1970s forward, their meeting between 2010 and 2011, and divergence thereafter, with Gun Culture 2.0 themes superseding Gun Culture 1.0 themes. Looking at the underlying data, from 2014 to 2019, the average annual coded advertising space reflecting Gun Culture 2.0 themes was $56.5 \%$ (range $=49.6$ to $68.7 \%$ ) while only $14.2 \%$ on average reflected Gun Culture 1.0 themes (range $=0$ to 25\%).

Notably, in the original study of The American Rifleman, the crossover from the declining Gun Culture 1.0 and the ascending Gun Culture 2.0 took place a few years later, in 2014, a year in which $45.3 \%$ of all advertising space coded reflected Gun Culture 2.0 themes, while only $15.9 \%$ reflected Gun Culture 1.0 themes (Yamane et al., 2019, pp. 21-22).

\section{Conclusion}

This systematic content analysis of gun advertising in Guns magazine was designed to replicate and test Yamane et al.'s (2019) study documenting a shift in the core emphasis of US gun culture from hunting and recreational shooting to armed selfdefense. The data show that the predominance of Gun Culture 1.0 themes in advertising persists through the 1980s and into the 1990s, when the center of gravity of gun culture begins to shift decisively toward the Gun Culture 2.0 themes of personal protection/self-defense and concealed carry. This trend continues through the 1990s and 2000s, with the two emphases crossingover in the 2010s. As reflected in advertising, in addition to other indicators such as self-reported reasons for gun ownership, Gun Culture 2.0 is now America's dominant and still expanding core gun culture today.

Like Yamane et al. (2019), this replication study is not without shortcomings. First, we use the content of gun advertising as an indicator of cultural change over time. Like other students of advertising, we cannot answer the question of whether advertising is only a "mirror" reflecting culture or is also a "mold" influencing it (Eisend, 2010). The most likely answer is that the causal arrow is two-headed and the process is iterative, but to conclude this with certainty requires an independent measure of social change, which is hard to come by over the long period under study here.

A second and related limitation is that a comprehensive understanding of culture-including advertising-requires understanding not only the production or "encoding" of culture as analyzed here. It also requires understanding the reception or "decoding" of culture (Hall, 1980). Here, a photo elicitation interview methodology would be a productive approach to tapping into the thoughts, meanings, and emotions consumers attach to particular advertisements (Harper, 2002; cf. Harcourt, 2006).

Third, more subtle, qualitative analyses of these changing themes would add flesh to the skeleton of trend data we have constructed here. For example, Dawson (2019) has recently explored the sacralization of the Second Amendment by the National Rifle Assocation. It is possible that the same process is reflected in gun advertising. Anecdotally, we have seen the gun manufacturer Springfield Armory advertising an AR-platform rifle called "The Saint". In addition, Carlson (2015), Metzl (2019), and Stroud (2016) all highlight the importance of class, race, and/ or gender dynamics in contemporary gun culture. The existing literature on race and gender imagery in advertising (Coltrane and Messineo, 2000; Goffman, 1979), therefore, could be profitably applied to gun advertising. 


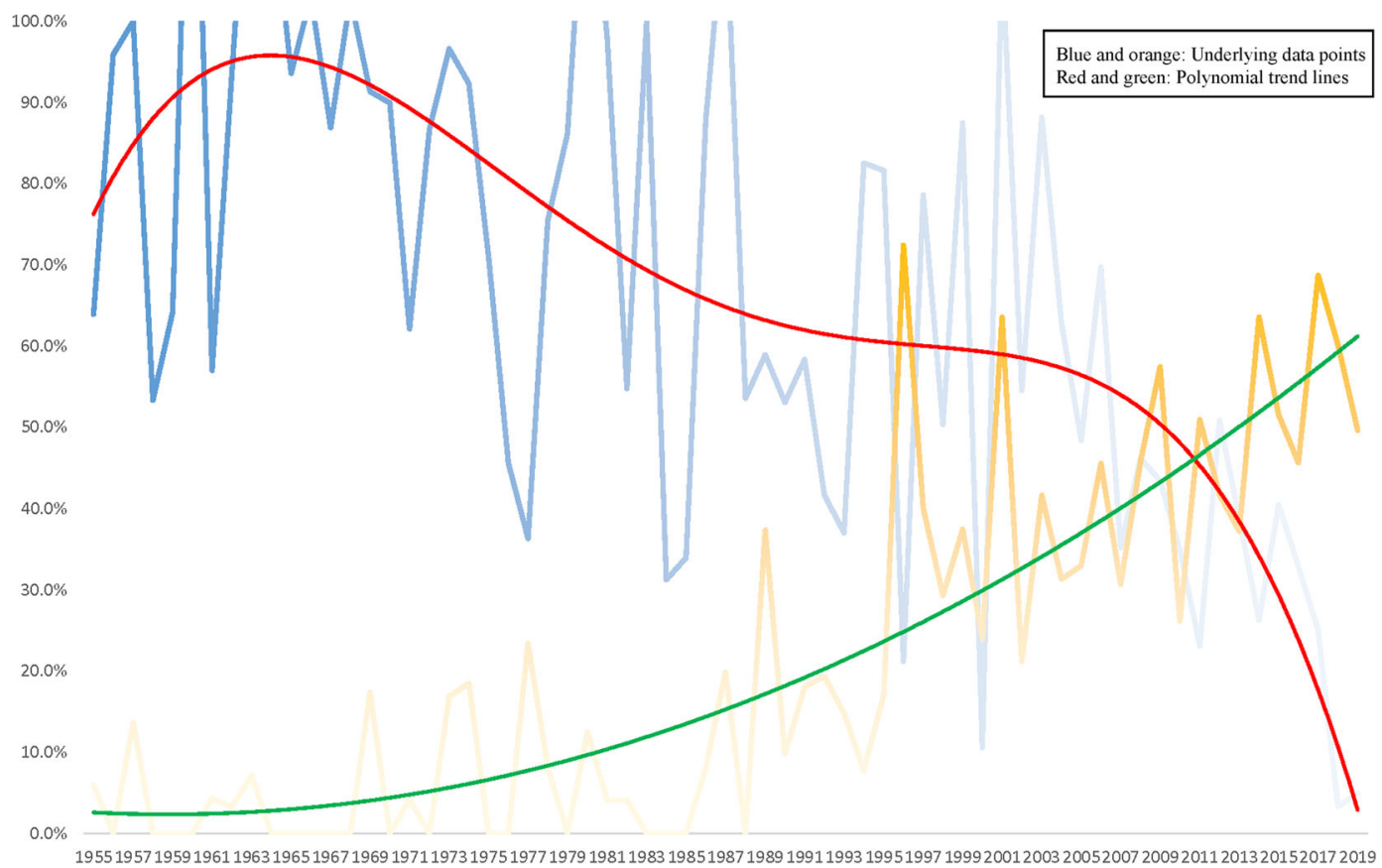

Fig. 6 Change in hunting/sport shooting compared to self-defense/concealed carry themes as percentage of total coded advertising space, Guns magazine, 1955-2019.

Finally, it is important to recognize that being a part of gun culture is not simply about holding a particular set of beliefs. According to Stebbins (2001, p. 54), "Serious leisure participants typically become members of a vast social world, a complex mosaic of groups, events, networks, organizations, and social relationships". The same is true for participants in both recreational and defensive gun culture. America is not just a "Gun Show Nation", to use Burbick's (2007) famous phrase, it is a nation of gun clubs, training classes, shooting events, network meet-ups, gun collectors and shooters associations. Kohn (2004) approaches gun culture this way in Shooters, but more solidly ethnographic work like hers is necessary. Going forward, further attention should be paid especially to the social organization of armed citizenship and concealed carry, building on Carlson's (2015) work, as well as the complex personal dynamics of becoming a gun carrier, following in Stroud's (2016) and Shapira and Simon's (2018) footsteps.

As Yamane (2017) has argued, social institutions-including the legal system, economy, and technology-shape American gun culture. These institutions require greater attention, as well. For example, the passage of shall-issue concealed carry laws facilitates the widespread practice of legally carrying guns in public. The growing practice of concealed carry also creates a number of new challenges for the individuals who do so, as well as for the broader social worlds (other people, spaces, places) in which they do so. The developing culture of armed citizenship addresses these challenges both through the "hardware" of material culture like guns, accessories, and other products, and the "software" of ways of thinking, legal frameworks, and the development of relevant abilities. Gun studies scholars are encouraged to study these aspects of Gun Culture 2.0 going forward.

\section{Data availability}

The dataset used in the current study are not publicly available as the authors are continuing to analyze it, but is available from the corresponding author on reasonable request.
Received: 27 November 2019; Accepted: 18 March 2020;

Published online: 15 April 2020

\section{Notes}

1 Some of the advertisements described here can be viewed online in the Roy Marcot Firearms Advertisement Collection, Cody, Wyoming. McCracken Research Library, Buffalo Bill Historical Center, Cody, Wyoming. For example, the Smith \& Wesson bicycle revolver ad (http://library.centerofthewest.org/cdm/ref/collection/MS111/id/ 50) and the Iver Johnson home revolver ad (http://library.centerofthewest.org/cdm/ ref/collection/MS111/id/1039).

2 No one knows definitively what percentage of Americans own how many total guns (on gun ownership rates, see "What Percentage of Americans Own Guns? Minimum Estimates", available at https://guncurious.wordpress.com/2019/02/11/why-surveysunderestimate-gun-ownership-rates-in-the-u-s/). Data from the 2015 National Firearms Survey (NFS) suggests that $28 \%$ of gun owners own just one gun, and the median number of guns owned is two. The mean number of guns owned, however, is nearly 5 , suggesting a skewed distribution. NFS data suggests that $14 \%$ of gun owners own half of the total gun stock in the US (Azrael et al., 2017).

3 Circulation data is the Alliance for Audited Media average for the six months ended 30 June 2019.

4 Although we completed this manuscript before the end of 2019, the magazine publishes its December issue in October, so we were able to randomly select 1 of 12 issues for 2019 .

5 We used the free reliability calculator, ReCal3: Reliability for $3+$ Coders, on Deen Freelon's web page: http://dfreelon.org/utils/recalfront/recal3/.

\section{References}

Azrael D, Hepburn L, Hemenway D, Miller M (2017) The stock and flow of U.S. firearms: results from the 2015 National Firearms Survey. RSF J Soc Sci 3:38-57. https://doi.org/10.7758/RSF.2017.3.5.02

Burbick J (2007) Gun show nation: Gun culture and American democracy. New Press, New York

Carlson J (2015) Citizen-protectors: the everyday politics of guns in an age of decline. Oxford University Press, New York

Coltrane S, Messineo M (2000) The perpetuation of subtle prejudice: race and gender imagery in 1990s television advertising. Sex Roles 42:363-389. https:// doi.org/10.1023/A:1007046204478

Cramer CE (2006) Armed America: the remarkable story of how and why guns became as American as apple pie. Thomas Nelson Inc., Nashville, TN

Cramer CE, Kopel DB (1994) "Shall issue": the new wave of concealed handgun permit laws. Tenn Law Rev 62:679-757 
Dawson J (2019) Shall not be infringed: how the NRA used religious language to transform the meaning of the Second Amendment. Palgrave Commun 5. https://doi.org/10.1057/s41599-019-0276-z

Diaz T (1999) Making a killing: the business of guns in America. New Press, The, New York

Dunbar-Ortiz R (2018) Loaded: a disarming history of the second amendment. City Lights Publishers, San Francisco

Eisend M (2010) A meta-analysis of gender roles in advertising. J Acad Mark Sci 38:418-440. https://doi.org/10.1007/s11747-009-0181-x

Goffman E (1979) Gender advertisements. Palgrave, London

Gramlich J, Schaeffer K (2019) 7 facts about guns in the U.S. (October 22). https:// www.pewresearch.org/fact-tank/2019/10/22/facts-about-guns-in-united-states/

Griswold W (2013) Cultures and societies in a changing world, 4th edn. SAGE Publications, Thousand Oaks, CA

Grossman RS, Lee SA (2008) May issue versus shall issue: explaining the pattern of concealed-carry handgun laws, 1960-2001. Contemp Economic Policy 26:198-206. https://doi.org/10.1111/j.1465-7287.2007.00094.x

Haag P (2016) The gunning of America: Business and the making of American gun culture. Basic Books, New York

Hall S (1980) Encoding/decoding. In: Centre for Contemporary Cultural Studies (ed.) Culture, media, language: working papers in cultural studies, 1972-79. Hutchinson, London

Harcourt BE (2006) Language of the gun: youth, crime, and public policy. University of Chicago Press, Chicago

Hardy DT (2012) American Rifleman. In: Carter GL (ed.) Guns in American society: an encyclopedia of history, politics, culture, and the law, 2nd edn. ABC-CLIO, Santa Barbara, CA

Harper D (2002) Talking about pictures: a case for photo elicitation. Vis Stud 17:13-26. https://doi.org/10.1080/14725860220137345

Hofstadter R (1970) America as a gun culture. American Heritage 21. http://www. americanheritage.com/content/america-gun-culture

Horkheimer M, Adorno TW (1944) Dialectic of Enlightenment. Stanford University Press, Stanford, CA, [2007]

Karp, A (2018) Estimating global civilian-held firearms numbers (Briefing Paper). Small Arms Survey, Geneva. http://www.smallarmssurvey.org/fileadmin/ docs/T-Briefing-Papers/SAS-BP-Civilian-Firearms-Numbers.pdf

Kohn AA (2004) Shooters: myths and realities of America's gun cultures. Oxford University Press, New York

Krippendorff K (2013) Content analysis: an introduction to its methodology, 3rd edn. Sage, Thousand Oaks, CA

Luke T (2019) Counting up AR-15s: the subject of assault rifles and the assault rifle as subject. In: Sarat A, Obert J, Poe A (eds) The lives of guns. Oxford University Press, New York, pp. 70-92

Metzl JM (2019) Dying of whiteness: how the politics of racial resentment is killing America's heartland. Basic Books, New York

Packard V (1957) The hidden persuaders. Longmans, Green, and Co., New York

Pergams ORW, Zaradic PA (2008) Evidence for a fundamental and pervasive shift away from nature-based recreation. Proceedings of the National Academy of Sciences 105: 2295-2300. https://doi.org/10.1073/pnas.0709893105

Peterson RA (1978) The production of cultural change: The case of contemporary country music. Soc. Res. 45:292-314

Pew Research Center (2013) Why own a gun? Protection is now top reason (March 12). http://www.people-press.org/2013/03/12/why-own-a-gun-protection-is-now-topreason/

Press A (1991) Women watching television: gender, class, and generation in the american television experience. University of Pennsylvania Press, Philadelphia

Rajala T (2012) Gun magazines. In: Carter GL (ed.) Guns in American society: an encyclopedia of history, politics, culture, and the law, 2nd edn. ABC-CLIO, Santa Barbara, CA, Volume 2

Saylor EA, Vittes KA, Sorenson SB (2004) Firearm advertising: product depiction in consumer gun magazines. Evaluation Rev 28:420-433. https://doi.org/ $10.1177 / 0193841$ X04267389

Schudson M (1984) Advertising, the uneasy persuasion: its dubious impact on american society. Basic Books, New York

Shapira H, Simon SJ (2018) Learning to need a gun. Qualitative Sociol 41:1-20. https://doi.org/10.1007/s11133-018-9374-2
Stebbins RA (2001) Serious leisure. Society 38(4):53-57

Steidley T (2019a) Sharing the monopoly on violence? Shall-issue concealed handgun license laws and responsibilization. Sociological Perspect 62:929-947. https://doi.org/10.1177/0731121419863787

Steidley T (2019b) The effect of concealed carry weapons laws on firearm sales. Soc Sci Res 78:1-11. https://doi.org/10.1016/j.ssresearch.2018.12.018

Stroud A (2016) Good guys with guns: the appeal and consequences of concealed carry. University of North Carolina Press, Chapel Hill

Taylor JD (2013) American gun culture: collectors, shows, and the story of the gun, 2nd edn. LFB Scholarly Publishing, El Paso, TX

U.S. Fish \& Wildlife Service (2018) 2016 National survey of fishing, hunting, and wildlife-associated recreation. U.S. Department of the Interior, Washington, DC

Wertz J, Azrael D, Hemenway D, Sorenson S, Miller M (2018) Differences between new and long-standing US gun owners: results from a national survey. Am J Public Health 108:871-877. https://doi.org/10.2105/AJPH.2018.304412

Winkler A (2011) Gunfight: the battle over the right to bear arms in America. W. W. Norton and Company, New York

Wright JD, Rossi PH, Daly K (1983) Under the gun: weapons, crime, and violence in America. Aldine Transaction, New Brunswick, NJ

Yamane D (2017) The sociology of U.S. gun culture. Socio Compass 11:e12497. https://doi.org/10.1111/soc4.12497

Yamane D (2019) "The first rule of gunfighting is have a gun": technologies of concealed carry in Gun Culture 2.0. In: Sarat A, Obert J, Poe A (eds) The lives of guns. Oxford University Press, New York, pp. 167-193

Yamane D, Ivory SL, Yamane P (2019) The rise of self-defense in gun advertising. The American Rifleman, 1918-2017. In: Carlson J, Goss K, Shapira H (eds) Gun studies: interdisciplinary approaches to politics, policy, and practice. Routledge, New York, pp. 9-27

\section{Acknowledgements}

We thank Wake Forest University students Elizabeth Puett, Eleni Angelides, and Jaboree Williams for their early work on this project. This research was supported by a grant from Wake Forest University's Social, Behavioral and Economic Sciences Research Fund.

\section{Competing interests}

The authors declare no competing interests.

\section{Additional information}

Correspondence and requests for materials should be addressed to D.Y.

Reprints and permission information is available at http://www.nature.com/reprints

Publisher's note Springer Nature remains neutral with regard to jurisdictional claims in published maps and institutional affiliations.

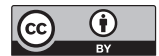

Open Access This article is licensed under a Creative Commons Attribution 4.0 International License, which permits use, sharing, adaptation, distribution and reproduction in any medium or format, as long as you give appropriate credit to the original author(s) and the source, provide a link to the Creative Commons license, and indicate if changes were made. The images or other third party material in this article are included in the article's Creative Commons license, unles indicated otherwise in a credit line to the material. If material is not included in the article's Creative Commons license and your intended use is not permitted by statutory regulation or exceeds the permitted use, you will need to obtain permission directly from the copyright holder. To view a copy of this license, visit http://creativecommons.org/ licenses/by/4.0/.

(C) The Author(s) 2020 